\title{
"Initium ut esset, creatus est homo": 1 Iris Murdoch on Authority and Creativity
}

\section{ABSTRACT}

In 1970 the British novelist and philosopher Iris Murdoch published both her thirteenth novel, A Fairly Honourable Defeat, and her best known work of philosophy, The Sovereignty of Good. Given the proximity of these publication dates, it does not surprise that there are many points of comparison between these two works. The novel features, for instance, a character writing a work of moral philosophy not unlike Murdoch's own The Sovereignty of Good, while another character exemplifies her moral philosophy in his life.

This article proposes a reading of the novel as a critical commentary on the philosophical work, focusing on the tension between creation and authority. While Murdoch considers humans to be first and foremost creative, she is at the same time wary of the misleading nature of any act of creation. For Murdoch, any creator and any creation-a beautiful picture as well as a watertight theory-may transmit a certain authority, and that authority may get in the way of acknowledging reality. It thus hinders the moral life, which for Murdoch should be thought of as a life of attention-to reality and ultimately to the Good-rather than a series of wilful creations and actions.

A Fairly Honourable Defeat queries the possibility and danger of creation, through different characters as well as through images of cleanliness and messiness. Thus, the character whose book of moral philosophy is challenged and who is found wanting when putting his ideas to practice, likes 'to get things clear' (176). Another character, whose interferences create the novel's drama, has a self-confessed 'passion for cleanliness and order' (426). The saint of the story, in contrast, does not interfere unless by necessity, and resides in one of the filthiest kitchens in the history of

1 Augustine, as quoted by Arendt 18. The quote is taken from The City of God, bk. XII, chap. 20. Arendt also provides a translation: "That a beginning be made man was created.” 
literature. Yet, none of the main characters exemplifies a solution to the tension between creation and authority found in Murdoch's philosophy. An indication of a solution is found in a minor character, and in his creations of outrageous bunches of flowers, unusual meals, and absurd interiors. Yet, its location in a subplot suggests that this solution is not in any way final. It is concluded that any final solution should not be expected, not in the least because of the pervasive nature of the tension between creation and authority, which goes well beyond Murdoch's own authorship.

\section{ABSTRACT}

A Fairly Honourable Defeat is Iris Murdoch's thirteenth novel. Published in January 1970 it precedes the publication of her best known work of philosophy, The Sovereignty of Good, by only a few months. ${ }^{2}$ Given the proximity of these publication dates it does not surprise that there are many points of comparison between these two works. The novel features, for instance, a character writing a work of moral philosophy, not unlike Murdoch's own The Sovereignty of Good, while another character exemplifies her moral philosophy in his life.

This article explores the relationship between the two works. More precisely, it reads A Fairly Honourable Defeat as a critical commentary on The Sovereignty of Good, focusing on the tension between creation and authority. While Murdoch considers any act of creation humans' most important characteristic ("We are all artists" [Metaphysics 315; cf. 323]), she is at the same time wary of its misleading nature. For Murdoch, any creation-a beautiful picture as well as a watertight theory-transmits a certain authority. The presence of such authority raises concerns about mistaking this creation, and its creator, for the idea of perfection or good that lies beyond:

One may of course try to "incarnate" the idea of perfection by saying to oneself "I want to write like Shakespeare" or "I want to paint like Piero." But of course one knows that Shakespeare and Piero, though almost gods, are not gods, and that one has got to do the thing oneself alone and differently, and that beyond the details of craft and criticism there is only the magnetic non-representable idea of the good which remains not "empty" so much as mysterious. (Sovereignty 61)

2 A Fairly Honourable Defeat is published in January, The Sovereignty of Good in July (Purton 118, 120 respectively). 
"One has got to do the thing oneself alone and differently." In A Fairly Honourable Defeat, I argue, Murdoch explores various ways of this "doing the thing oneself," as she questions the authority of creator and creation. Her argument in the novel, moreover, often comes in images of cleanliness and messiness, and of creating order in chaos. My argument consists of three parts. I first present the main ideas from The Sovereignty of Good. I then proceed to make some remarks about the relation between philosophy and literature, before I discuss the novel.

The Sovereignty of Good is probably Murdoch's best known work of philosophy. It consists of three essays, which were all published before: "The Idea of Perfection" (1962), "On 'God' and 'Good"” (1969), and "The Sovereignty of Good Over Other Concepts" (1967). Together they form a determined criticism of the contemporary moral philosophy and its emphasis on will and rational decision. In response, Murdoch develops a moral philosophy which emphasizes the constant work of the creative imagination rather than intermittent instances of will, and whose metaphors are those of vision rather than action. Moreover, she endorses a notion of the Good as central to moral philosophy.

In the earliest of the three essays, "The Idea of Perfection," Murdoch presents her ideas through a lengthy comparison with Stuart Hampshire's Thought and Action (1959) and "Disposition and Memory" (1962), while in the two later essays, "On 'God' and 'Good"' and "The Sovereignty of Good Over Other Concepts" the opposing position is presented much more succinctly and generally (cf. Altorf $57 \mathrm{ff}$.). Here, Murdoch even combines her criticism of analytical philosophy and existentialism in a single image, suggesting that they suffer from a similar infection: "Existentialism has shown itself capable of becoming a popular philosophy and of getting into the minds of those (e.g. Oxford philosophers) who have not sought it and may even be unconscious of its presence" (45-46).

Indeed, throughout The Sovereignty of Good Murdoch's criticism is at its most forceful in a cumulative number of images. In "The Idea of Perfection" Murdoch criticizes Hampshire by comparing his notion of morality to a visit to a shop, in which the moral agent can objectively choose the possible action open to him or her (8). In "'On 'God' and "Good" the moral agent of "existentialism" is described as "an isolated principle of will, or burrowing pinpoint of consciousness, inside, or beside, a lump of being" (47), and in "The Sovereignty of Good Over Other Concepts” even to Milton's Lucifer (78). These images point to Murdoch's objections to the existing moral philosophy. Murdoch does not just reject the arguments, but also has empirical and moral objections. She does not think people are like this, or even that they should portray themselves thus (9). 
What these images fail to acknowledge, Murdoch argues, is the constant struggle of any moral life. Morality is not limited to points of decision, which can be viewed with absolute clarity thanks to humans' ability to always "step back" (Existentialists 194). For Murdoch, the moral life is a pilgrimage of constant creation and destruction of images (Metaphysics 31718), under the authority of the Good (Sovereignty 88ff.). The Sovereignty of Good is perhaps best summarized by the following quote from Simone Weil: "We should pay attention to such a point that we no longer have the choice" (qtd. in Murdoch, Existentialists 159; cf. Altorf and Willemsen 13).

Murdoch typically refers to art to explain the status of an attentive mind essential for morality. Art is not identical to morality, but the best indication of what morality is like. The following quotation introduces not just the role of art in her moral philosophy, but also shows how Murdoch's writing in its constant searching, questioning tone exemplifies the state of mind she seeks to describe:

Art ... good art, not fantasy art, affords us a pure delight in the independent existence of what is excellent.... Art then is not a diversion or a side-issue, it is the most educative of all human activities and a place in which the nature of morality can be seen.... An understanding of any art involves a recognition of hierarchy and authority. ... Good art ... is something pre-eminently outside us and resistant to our consciousness. We surrender to its authority with a love which is unpossessive and unselfish. (Sovereignty 83, 85-86)

The relation between art and morality can be understood from the distinction Murdoch makes between good art and bad art—or fantasy art. Good art, as exemplified by the works of Shakespeare, Tolstoy, Velazquez or Titian (Sovereignty 63), is most of all characterized by its ability to resist the selfish tendencies of human nature. Murdoch does not have a very positive image of human beings. Taking her cue from Freud she holds that humans are "naturally selfish" (Sovereignty 76; cf. 50ff.). Good art challenges these natural egoistic tendencies in a way which is exemplary for moral philosophy. "We surrender to its authority with a love which is unpossessive and unselfish."

The suggestion to surrender is at odds with the earlier "One has got to do the thing oneself alone and differently." Even though Murdoch understands human beings as essentially creative, and moral pilgrimage as a creative process, the ultimate metaphor is one of vision and obedience. Wilful creation ("I want to write like Shakespeare") is considered with suspicion. Indeed, in Metaphysics as a Guide to Morals Murdoch concludes-albeit with an image - to the end of all imagery. Images should be regarded "as ladders to be thrown away after use" (318). 
This tension has been subject of various studies, yet-I would argue-Murdoch herself was the first to notice it. ${ }^{3}$ In A Fairly Honourable Defeat she proves to be one of her most prominent critics. Yet, before I start discussing this novel, it should be noted that Murdoch famously argued against my undertaking - that there is no premeditated relation between her philosophical and literary work. In the 1978 interview with Bryan Magee she declared to feel "an absolute horror of putting theories or 'philosophical ideas' as such into my novels." Any philosophy in her novels appeared by incident, because, Murdoch argued: "I happen to know about philosophy. If I knew about sailing ships I would put in sailing ships; and in a way, as a novelist, I would rather know about sailing ships than about philosophy" (Existentialists 19-20).

This comment has baffled her readers, for there are numerous references to her philosophical work in her novels: characters use images from her philosophical work, have lengthy philosophical conversations, or write philosophical books which resemble The Sovereignty of Good. It seems improbable that these references could have been replaced by different ones to sailing ships. A discussion about love suggests itself as a tool of interpretation and a major concern for the novels in a way that one about, for instance, "sailing to the wind" never could. Murdoch's characters often attempt to live her philosophy. And of course, on the various occasions in which Murdoch responded to papers on her work, she seldom seemed filled with horror when papers explored the relation between novels and philosophy (see, for instance, the discussions in Todd, Encounters with Iris Murdoch).

I have argued elsewhere that the interview with Magee should not be understood at face value (Altorf 2-6). I suspect that Murdoch was conscious of being the only woman in a series called 'Men of Ideas," though this is difficult to verify. ${ }^{4} \mathrm{~A}$ more immediate reason I found in Magee's introduction and questions, which ban many points of overlap between philosophy and literature from the conversation. In his introduction, Magee dismisses the possibility that writing style can be of significance for philosophical ideas, and later suggests to Murdoch that novel writing is radically different from writing philosophy, and that the sentences in her novels are very different from those in her philosophy. The former are "opaque ... rich in connotation, allusion, ambiguity," the latter "transparent ... saying only one thing at a time." For Magee, then, philosophy

\footnotetext{
3 Peter Conradi has systematically discussed this issue as one between the saint and the artist in Murdoch's novels (Saint and Artist, passim).

4 On Murdoch's ambiguous relation to feminism, see for instance Johnson, Griffin, Grimshaw, Altorf.
} 
is straightforward and unambiguous, whereas literature is messy and ambiguous (Existentialists 3-4).

Literature is messy, philosophy is tidy. Even if Magee does not use these images, they seem appropriate in the present context-not in the least because A Fairly Honourable Defeat features one of the filthiest kitchens in the history of literature. (I'll come back to it later.) The image of messiness points to an underlying difficulty which does not disappear by questioning the status of Murdoch's answers in an interview. It reaffirms Murdoch's observed philosophical unease about creation, in particular the wilful imposition of form in her novels. Murdoch's novels may be highly structured, but-A.S. Byatt very rightly observed-"A novel, she says, has got to have form; but she seems to feel a metaphysical regret about it" (Byatt 216-17; cf. Wood). In The Sovereignty of Good Murdoch replaced God with Good, and by doing so deprived the act of creation of its divine precedence. In A Fairly Honourable Defeat it positively becomes diabolical.

A Fairly Honourable Defeat shares various characteristics with Murdoch's other 26 novels (cf. Todd, "Veertig"). The reader is introduced to a small group of friends and relatives of upper middle class Londoners-largely civil servants and academics - who find their reasonably peaceful existence disturbed by the arrival of an enchanter. A period of only a few weeks will witness the shattering of long-held certainties, the end of relationships, and the abandonment of moral principles. One of the characters will die, and at the end of the novel the group of friends is shattered over the world.

The enchanter in A Fairly Honourable Defeat is Julius King, who opens and ends the novel, and who has been understood to frame it (Conradi, Saint and Artist 205; cf. Gordon 68). His name are the novel's first words, when uttered in a conversation of as yet anonymous speakers. They turn out to be "handsome" and "altruistic" Hilda and Rupert Foster, sitting at their swimming pool, on the evening of their twentieth wedding anniversary (Fairly Honourable Defeat 11). In the last chapter we find Julius King in Paris. Having started the chain of events which has upset the lives of a cosy group of friends, he is now enjoying the luxuries of the city: the Louvre, an opera, and good food in a restaurant recommended by Rupert. "Life was good" (447).

Julius King's return to London follows his break-up of his relationship with Morgan Brown, sister to Hilda Foster, and still married to Tallis Brown, the saint of the story. Morgan also returns to London at the beginning of the book, but not with Julius. Julius is a biologist, who worked on chemical warfare, but stopped because-as he claims-he got bored (218). According to his own account, he starts for more or less the same reason the deception which leads to the break-up of Hilda and Rupert's happy marriage, the destruction of Rupert's book by their son Peter, and eventually to Rupert's death (403). As a subplot, Julius also manages to almost 
end the relationship between Simon, Rupert's younger brother, and Axel, a colleague of Rupert's.

Yet, Julius's major test concerns Rupert and Morgan. At the start of the novel Rupert is about to finish his book on moral philosophy, on which he has worked for eight years. Rupert calls himself a "Sunday-metaphysician" (27), though he also prides himself on his "philosophical training" (182), and academic achievements. He studied philosophy at Oxford, where he also did a $\mathrm{PhD}$, and now works as a civil servant in Whitehall. The book has been written in evenings and weekends.

Julius is not impressed with Rupert or with his writing, but his decision to test them against reality-together with Morgan's "broken down version of Rupert's stuff" (404)—is more or less made impromptu (403, 408). He creates a farce that would not be out of place in any Shakespearean comedy (cf. Todd, Shakespearean Interest; Conradi, Saint and Artist). Through an exchange of old love letters, adjusted for the occasion, he makes Rupert and Morgan believe themselves to be the object of the other's passionate love. Both of them neglect to check the verity of the claims, but instead—as Julius later reflects—start a "sentimental pussyfooting around [which] produce[s] such a web of emotional confusion that they would no longer be in a position to verify anything" (406). To the outside world and even to themselves, it is no longer obvious that there was no passionate love at the start.

The test goes horribly out of hand, and the consequences surprise even Julius (408-09; cf. Gordon 67). Once Hilda assumes that her husband and sister are having an affair, the stable and seemingly unbreakable relationship between Hilda and Rupert is shattered, Rupert's book is destroyed by his son Peter - with a little help from Julius — and in the end even Rupert himself will not be saved. Drowned in the alcohol that has flown richly throughout the novel, he falls in the pool at the lovely Primrose house and drowns. A joke (Julius's?, Murdoch's?) has gone badly out of hand.

While it is not uncommon for one of the characters to die in Murdoch's novels, the ridicule and, later, violence and utter destruction of Rupert's work and life have always seemed to me out of order. At the end of the book, when the swimming pool is full of leaves and his wife has left for America with his sister, there is very little left of him. This destruction is all the more remarkable, as his ideas seem to resemble Murdoch's own philosophical work. And yet Rupert's book is discredited from the very start. The other characters are either scathing about it (Axel, Julius, Peter), or admire it without any acknowledgement of its content (Hilda, Simon).

Before looking for a possible explanation of Rupert's complete destruction, it is necessary to wonder whether such an explanation is to be had at all. When things happen in real life, it is not always possible to point 
at one cause, or any cause at all. This is how Julius reasons when trying to explain the events (427ff.). Yet, a novel is not real life, and this novel is not just a realistic novel, even though it can be read as one (Grimshaw 36; Conradi, Saint and Artist 230). Moreover, this is a highly structured novel. Things do not happen by chance. Instead, almost all events in the novel are foreshadowed by earlier comments or events. Thus, the first few chapters do not only introduce the main characters, but also predict their actions. Hilda for instance suggests that "Julius is someone who might do anything because he was bored" (Fairly Honourable Defeat 13), and Rupert is said to be "unstable" and "lucky," because "he hasn't been tried" (35). There are constant concerns that animals-insects, but most of all the hedgehogwill drown in the pool, as they lack sufficient "sense of self-preservation" (16). The hedgehog indeed drowns before Rupert does (353). In another premonition of events to come, Rupert finds the "neat order [of his notebooks] destroyed by Julius's inquisitive hand" (226).

What then could be the role of Rupert's complete destruction in this highly structured novel? An obvious answer may be found in relation to Murdoch's own writing. Yet, as the reader does not know the exact content of Rupert's book, it is impossible to tell the extent in which it resembles Murdoch's own The Sovereignty of Good. Even though, as Cheryl Bove observes, "none of [his] ideas is contrary to Murdoch's moral philosophy," that does not mean that it is the same (Bove 69). Moreover, even if one assumes that Rupert's work resembles Murdoch's, it is difficult to decide the significance of its destruction. It could just as well express her dissatisfaction with her own ideas (cf. Conradi, Iris Murdoch 501), as pre-empt any criticism. Even the toughest reviewer would have difficulty outdoing Rupert's destruction.

Yet, I think yet another option more convincing. In A Fairly Honourable Defeat Murdoch is concerned, I would argue, not just or specifically with her own philosophy, but with all philosophy or all theory, when given more authority than deserved (cf. Conradi, Saint and Artist 215). This is especially true in relation to Rupert's work, as well as Morgan's new found notion of love. From the very beginning it is suggested that Rupert's theory does not stand a chance against reality (Fairly Honourable Defeat 35). Axel mocks that Rupert's book will be a "guide to behaviour" so that he could "follow it slavishly" (46). Julius explains to Rupert that any attempt at knowing the truth is illusion, or theory (222). Tallis considers Morgan "hopelessly theory-ridden" (213).

The endorsement or condemnation of theory is often accompanied by imagery of cleanliness and messiness. This is most evident in the contrast between Rupert on the one hand, and Tallis on the other. Rupert is, like Murdoch's protagonists in other novels, little affected by time. 
He is "boyish-faced" (11) with faded though still blond hair. Life does not have many surprises for him, and he is keen to solve any remaining issues sooner rather than later. Thus, at an early stage he summons Tallis because, as Hilda muses, he "wanted to get things clear. Men so often did" (176). In the conversation, Rupert urges Tallis to show the "authority of a husband" to get Morgan out of the "sordid and wretched world" she has been living in, the world of "prevarication and muddle and shabby thinking" (181-82, cf. 213).

Tallis, in contrast-whom Murdoch considered "the only one real saint as it were, or symbolic religious figure" in her novels (Dooley 108)is from the very beginning associated with messiness (Fairly Honourable Defeat 20). He has difficulties making ends meet and takes too many jobs without being able to do any of them to satisfaction. He lives with his father, who dislikes him. He remains married to Morgan, who despises him. Every chance of changing this relationship is brutally interrupted by the entrance of one of the characters. He rarely finishes sentences when writing his lectures $(105,445)$. According to himself and others, he lives in a muddle and thinks muddled. He does not know how to sort out the junk from Morgan's stuff she left at their home (208). After meeting Morgan a few times, he finds that "his physical love for Morgan was becoming unhinged and getting all mixed up with the muckheap of his mind" (210-11). He is short, has freckles and a bumpy forehead $(83,118)$. His clothes are often dirty (123).

Yet, most striking of all of these allusions I find the image of Tallis's kitchen. As it is one of the more striking images from Murdoch's oeuvre, it deserves a lengthy introduction. Its first description in the novel is given by Hilda:

It looked much as usual. The familiar group of empty beer bottles growing cobwebs. About twenty more unwashed milk bottles yellow with varying quantities of sour milk. A sagging wickerwork chair and two upright chairs with very slippery grey upholstered seats. The window, which gave onto a brick wall, was spotty with grime, admitting light but concealing the weather and the time of the day. The sink was piled with leaning towers of dirty dishes. The draining board was littered with empty tins and open pots of jam full of dead or dying wasps. A bin, crammed to overflowing, stood open to reveal a rotting coagulated mass of organic material covered with flies. The dresser was covered in a layer, about a foot high, of miscellaneous oddments: books, papers, string, letters, knives, scissors, elastic bands, blunt pencils, broken biros, empty ink bottles, empty cigarette packets and lumps of old hard stale cheese. The floor was not only filthy but greasy and sticky and made a sucking sound as Hilda lifted her feet. (68) 
This kitchen does not leave any of the characters unmoved. All who dare enter it feel the need to respond. Their comment is one of condemnation or correction. Yet, while most people prefer not to enter this kitchen, it is the background to crucial conversations between Tallis and Julius. Indeed, it is Julius who actually cleans it, near the very end of the novel, after Rupert's death (426ff.). His cleaning, it should be added, has little lasting result. The kitchen soon returns to its usual state.

The kitchen has also elicited strong responses from its readers. As with other extravagant aspects of Murdoch's novels-for instance the dishes created by Bradley Pearson in The Sea, The Sea (1978) - interviewers could not hide their disgust. Thus, Jo Brans admits being "horrified" at the state of Tallis's kitchen: "there's sticky substance all over it, and the dirty milk bottles in which various things are growing, and really just this sort of horrifying filth." While Murdoch's initial response is evasive ("I must say, I don't mind filth as much as you do"), she later explains the purpose of the filth: "it's symbolic of the situation that nowadays the holy man is sort of shaky, hopeless, muddled, he hasn't got a place. Somebody else has to clean up his kitchen and so on" (Dooley 165-66). Tallis, the holy man, has got no place, or as Hilda puts it in the novel: "Hilda thought, wherever Tallis is there's always muddle! Then she thought, this is unjust. Wherever there is a muddle, there Tallis is" (Fairly Honourable Defeat 178).

Commentators have explained Tallis's messiness as exemplifying the important virtue of acknowledging contingency. As David Gordon argues: "For Murdoch, mess ('contingency') is the salient quality of the world around us when perceived by a selfless consciousness" (65). Tallis bears the contingency, while Julius in his disgust for it plots (Gordon 36; cf. 19 and 65). Tallis's place in this world - the place of saints-is not decided by themselves, but by contingency, by what they find around them. ${ }^{5}$

And yet, Tallis does intervene. He is, as Gordon rightly notes, not as passive as Ann Peronett in An Unofficial Rose (37). Moreover, his interventions are crucial: the accurate blow in the Chinese restaurant prevents a threatening situation from getting out of hand (Fairly Honourable Defeat 241), and the decision to phone Hilda puts an end to Julius's plot, even though it cannot prevent the tragic death of Rupert (409). Yet, it is obvious that these are not wilful actions, but the result of attention-in a way predicted by Tallis, when he reassures Rupert and Hilda: "When I see what to do, I'll do it" (181; though cf. 221 where Rupert uses the same words). It is as if Tallis's whole life has to be directed towards doing good. Even if

5 At the same time, the kitchen as no place also exemplifies the symbolic role of Tallis and Julius, as high incarnations. This is the explanation provided by Murdoch in several interviews (see for instance Dooley 50-51, 73-75; cf. Conradi, Saint and Artist 205). 
he cannot always do good, he is not allowed to waste any time or effort on cleaning the kitchen, or even to finish the sentences in his lectures. Tallis does not wilfully create, but only acts from necessity.

In Tallis Murdoch has succeeded in creating a saint for her moral philosophy. Yet, this feat comes at a cost. Tallis is doomed by his creator to stay in a filthy kitchen, to take on too many jobs, to continue a troubled relationship with his father, as well as with his wife, and to rarely finish his sentences, let alone lectures. Others act and create. Even Tallis's lodger, the Sikh bus driver who was the object of discrimination, has found a cause for action at the end of the novel (440). In Tallis, Murdoch also presents an alternative to her earlier misgivings about theory. It is made clear from the very beginning that in this respect also Tallis is Rupert's contrary. The latter, as Hilda rightly observes, has to mention about once a month that Tallis only got a second $(22,25)$. Tallis stumbles when Peter asks him why stealing is bad, whereas both Rupert and Julius later provide him with coherent exposés (182-83, 337 respectively).

The successful creation of this saintly character does not resolve Murdoch's ambiguous attitude to creation. On the contrary. It introduces the contradiction in terms of the successful creation that condemns its own act of existence. Even more importantly, in the opposition between (good) Tallis's concern for contingence, and (evil) Julius's wilful interventions, Murdoch's own novel writing resembles the latter-not the former. The image of the wilful creator-Murdoch the author-is Julius. Yet, as Gordon rightly observes, Murdoch is curiously coy about any relation between Julius and her own act of creation (Gordon 68). Creation is obviously not divine. It is the act of-whom some consider-the Devil (Conradi, Saint and Artist 205).

It seems, then, that A Fairly Honourable Defeat reaffirms Murdoch's philosophical wariness of creation: Rupert is destroyed because of his theories, Julius's plotting is shown to be evil, and Tallis is only allowed a few acts from necessity in his otherwise messy life. Even more than her philosophical work, the novel emphasizes the misguiding nature of any creation, or creator.

Yet, this is not the full story. One more suggestion presents itself when considering the notion of gender in this novel, a concept that has become a relatively recent object of Murdoch studies. ${ }^{6}$ A Fairly Honourable Defeat features three characters who cross gender: Tallis, Morgan, and Simon. Tallis is often portrayed as feminine. Hilda compares him to her husband thus:

\footnotetext{
6 Cf. footnote 4.
} 
How different these two are, thought Hilda ... Rupert is so strong and firm, so typically masculine and so marvellously honest. He wants complete information and straight answers and unambiguous positions. He wants clarifications and rational policies. Tallis is so much more indefinite and feminine. (179)

Significantly, the distinction between the genders runs along the same lines as that of theory. Thus, Tallis's wife, "clever" Morgan, who has a doctorate in glossematics, is said to have liked to be a boy (16). When in an absurdly comical scene, she dresses in Simon's clothes, the latter exclaims: "My God, Morgan, you look just like a chap!" The narrator hastens to explain that Morgan looked like "a clever boy, not even raffish, not even a dandy, just hard and clever" (165).

Simon is the third character said to cross gender divisions. Axel accuses him of having "the taste of a suburban housewife" (75). Peter sneers at him, for his dancing while wearing a wreath of roses (134), and Julius calls him "feminine," because: "All the little dainty touches in this room are obviously Simon's work. The cunning way those cushions are put, the graceful looping back of the curtains, the particular arrangements of the flowers, indeed the presence of the flowers" (305).

In this last character one more image of creation is found. Simon-as the other feminine characters (Hilda and Tallis) - may not know much theory. Indeed, even in the field in which he should be the expert, he is often corrected by Axel (35). Yet, Simon is also the creator of outrageous bunches of flowers, of wonderful and original interiors, dishes, and even of outrageous outfits for himself and others. Simon is the master of abundant creation, and almost each time he is censured or ridiculed for it by the male theorists. Simon is, moreover, one of the few characters to come out of the period of enchantment relatively unaffected. We leave him at the very end, drinking "excellent" wine in the garden of a French hotel with "in his veins the warm anticipation of new happiness" (437). Admittedly, he feels slightly guilty and sad, but not very much so. The author has let him off. His comical, frivolous art of creation is redeemed in the authoritarian fiat of his happiness. ${ }^{8}$

7 Simon's femininity is of course also an expression of a then popular image of homosexuality (Grimshaw 38ff.). Commentators agree that Murdoch's portrayal of the relationship between Simon and Axel is exceptional for its time (Conradi, Saint and Artist 204; Gordon 144; Bove 70; Grimshaw 37).

8 Significantly, Richard Todd comes to a similar conclusion, though from a different starting-point. He argues that Murdoch uses Shakespearean comic devices to solve her philosophical and literary problems (Shakespearean Interest 80-81). And yet another, similar explanation may be found in Simon at one point being crowned with a crown of roses, a crown of thorns-as a comical Christ (133)? Unfortunately, I have had to leave the 
A Fairly Honourable Defeat thus does propose a solution to the ambiguity central in The Sovereignty of Good, even if it is hidden in a subplot. Yet, I would hesitate to consider this solution final, or even to liken Murdoch's creations to Simon's-even though there are obvious points of comparison. Murdoch's wariness of existing images of creation and authority goes beyond the particularity of her authorship. It signifies a much wider challenge to authority, which can be put in terms of religion (the creator God) or gender. Murdoch was part of a generation of women philosophers, who despite their relatively novel position, emphasized their ordinariness. Yet, there is a growing amount of evidence that the existing imagery of authority did not always suit (cf. Rowe; Midgley 122-23). Murdoch's quest for an understanding of creation that is neither too authoritarian nor evil is a common quest, that cannot have a quick or easy answer. Yet, $A$ Fairly Honourable Defeat encourages us to start looking for it. The abundance of imagery in the novel has been far from fully explored, and provides further direction-as does Simon's ridiculous bouquet of flowers - "meant to be an absurdly large bunch" (35).

\section{WORKS CITED}

Altorf, Marije. Iris Murdoch and the Art of Imagining. London: Continuum, 2008.

Altorf, Marije, and Mariëtte Willemsen. "Iris Murdoch en de verbeelding van het Goede." Introduction. Over God en het Goede. By Iris Murdoch. Trans. and intro. Marije Altorf and Mariëtte Willemsen. Amsterdam: Boom, 2003: 7-30.

Arendt, Hannah. Willing. New York: Harcourt, 1978. Vol. 2 of The Life of the Mind. 2 vols. 1978.

Bove, Cheryl. Understanding Iris Murdoch. Columbia: University of South Carolina Press, 1993.

Byatt, A.S. Degrees of Freedom: The Early Novels of Iris Murdoch. 1965. London: Vintage, 1994.

Conradi, Peter. Iris Murdoch: A Life. London: HarperCollins, 2001.

---. The Saint and the Artist: A Study of the Fiction of Iris Murdoch. 1986. London: HarperCollins, 2001.

Gordon, David. Iris Murdoch's Fables of Unselfing. Columbia: University of Missouri Press, 1995.

Griffin, Gabriele. The Influence of the Writings of Simone Weil on the Fiction of Iris Murdoch. San Francisco: Mellen University Press, 1993.

religious imagery (including the relation between Tallis and his father) largely unexplored in this article. 
Grimshaw, Tammy. Sexuality, Gender, and Power in Iris Murdoch's Fiction. Madison: Fairleigh Dickinson University Press, 2005.

Johnson, Deborah. Iris Murdoch. Brighton: Harvester, 1987.

Midgley, Mary. The Owl of Minerva: A Memoir. London: Routledge, 2005.

Murdoch, Iris. Existentialists and Mystics: Writings on Philosophy and Literature. London: Chatto \& Windus, 1997.

---. A Fairly Honourable Defeat. 1970. London: Penguin, 1972.

---. Metaphysics as a Guide to Morals. 1992. London: Penguin, 1993.

---. The Sovereignty of Good. 1970. London: Routledge, 2001.

Purton, Valerie. An Iris Murdoch Chronology. Basingstoke: Palgrave Macmillan, 2007.

Rowe, Margaret. "Iris Murdoch and the Case of 'Too Many Men." Studies in the Novel 36.1 (Spring 2004): 79-94.

Spear, Hilda. Iris Murdoch. 1995. Basingstoke: Palgrave Macmillan, 2007.

Todd, Richard, ed. Encounters with Iris Murdoch: Proceedings of an Informal Symposium on Iris Murdoch's Work held at the Free University, Amsterdam, on 20 and 21 October 1986. Amsterdam: Free University Press, 1988.

---. Iris Murdoch: The Shakespearean Interest. Plymouth: Vision, 1979.

---. "Iris Murdoch: veertig jaar romanschrijven." Wijsgerig Perspectief $35.3(1994 / 5): 66-71$.

Wood, James. "Iris Murdoch's Philosophy of Fiction." The Broken Estate: Essays on Literature and Belief. London: Cape, 1999: 174-85. 